\title{
Analysing the Sustainability of Urban Development: A review on the Potential Use of Volunteered Geographic Information
}

\author{
Nabila Ibrahima , Uznir Ujanga , Ghazali Desa ${ }^{\mathrm{a}}$, Azman Ariffin ${ }^{\mathrm{a}}$ - (nabilagis, ghazali.desa)@gmail.com, (mduznir, \\ azmanariffin)@utm.my
}

${ }^{\text {a}}$ Faculty of Geoinformation and Real Estate, Universiti Teknologi Malaysia

KEYWORDS: Volunteered Geographic Information, VGI, Sustainable Urban Development, GIS

\begin{abstract}
The challenges of how to ensure sustainable urban development are currently one of the important agenda among governments around the world. The stakeholders require the latest and high volume of geographic information for the decision making process to efficiently respond to challenges, improve service delivery to citizens, and plan a successful future of the city. However, it is timeconsuming and costly to get the available information and some of the information is not up-to-date. Recently, GeoWeb 2.0 technological advances have increased the number of volunteers from non-professional citizen to contribute to the collection, sharing, and distribution of geographic information. The information known as Volunteered Geographic Information (VGI) has generated another approach of spatial data sources that can give up-to-date, huge volume of data, and available geographic information in a low cost for various applications. With this in mind, this paper presents a review of literature based on the potential use of Volunteered Geographic Information (VGI) in measuring sustainability of urban development. The review highlighted that social, economic, and environment as three pertinent pillars relating to the use of VGI for measurement sustainable urban development.
\end{abstract}

\section{INTRODUCTION}

Many developing countries, including Malaysia are entering the stage where the urbanization is increasing rapidly. By 2030, approximately 4 billion people will live in cities of the developing world (UN Forum, 2006). An increasing of population and rapid growth of economic and social activities in urban areas causes resources usage increase, pollution, destroy the environment, and social problems (Grim et al. 2008; Xing et al. 2009).

These challenges have led to the concept of sustainable development in urban planning. The concept of sustainable development involves three fundamental components; social, economic, and environment (Ciegis et al. 2009 and Yusof et al. 2008). The planning of activities and services, and subsequent administration, therefore, has a critical role in securing balanced environmental protection and socioeconomic development in terms of sustaining human activity now and into the future. Issues in sustainable urban development include how to monitor growth and change across the city and to forecast areas of risk. Geographic information has increasingly played an important role as one of the resources to help in support sustainable development (Broekhof and Marwijk, 2012).

New interactive web services are intensifying changing the way in which volunteers from non-professionals can create digital spatial data and maps, individually and collectively, to produce new forms of digital spatial data that some term 'Volunteered Geographic Information' (Goodchild, 2007; Elwood, 2008; Idris et al., 2014; Ariffin et al., 2014). The contribution of many volunteers to geographic information increase the potential for various applications in contributing to decision and policy making processes (Seeger, 2008; Genovese and Roche, 2010). In measuring sustainability of urban development, VGI can be used as an alternative to the decision maker that needs faster updating cycles (Song and Sun, 2010), a requirement to gather additional attribute information, and reducing production cost (Coleman, 2010).
In the pursuit of this goal, this paper conducts a review to find out the current state of the scientific literature with regard to the VGI applications that are related to sustainable urban development. This paper is firstly covers the introduction and background of the study, including an overview concept of the sustainable urban development and VGI. Second, the assessment of the literature on the use of VGI for sustainable urban development based on three pillars; social, economic, and environment is discussed. Finally, conclusions are drawn on the potential use of VGI in measuring sustainability of urban development.

\section{SUSTAINABLE URBAN DEVELOPMENT CONCEPT}

A common definition of sustainable development is from Brundtland report published in 1987 (Scherrer, 2009). In this report, the UN (United Nations, 1987) defines sustainable development as a development that meets the need of the present without compromising the ability of future generations to meet their own needs. The definition of sustainable development emphasizes the dynamic aspect of sustainability. Generally, sustainable development refers to maintaining development over time. Another common feature of sustainable development is three pillars; social, economic, and environment as shown in Figure 1 (e.g.; Green et al., 2012 \& Schoolman et al., 2012).

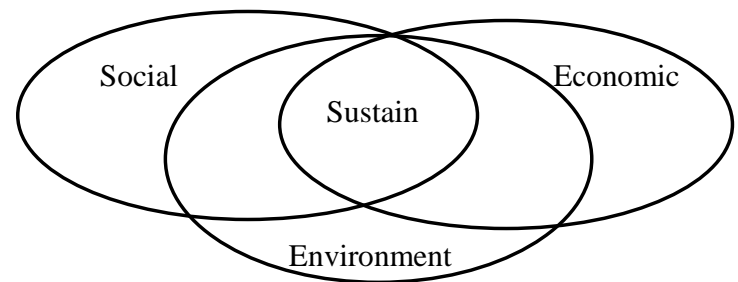

Figure 1: Three pillars of sustainable development (Source: Green et al., 2012) 
Consequently, every plan or activity related to urban development should take into account these interrelations. A plan or program favouring just one or two of these dimensions, will not contribute to sustainable development. It is because sustainable urban development is a process of getting these entire three development pillars into balance with one another. These three elements should therefore not to be perceived as independent, but rather as a complete frame of elements that equally contribute to reach the same goal.

\section{VOLUNTEERED GEOGRAPHIC INFORMATION CONCEPT}

The term "Volunteered Geographic Information" is firstly introduced by Goodchild in 2007 (Coleman et al., 2009). Volunteered Geographic Information or VGI refer to the activities of creation, collection, and distribution of geographic information by citizens using the Web (Goodchild, 2007). Recent development in communication technologies and information allows many peoples, including individual and data producer with a reliable internet connection generates and publish their maps and geographic information through Web 2.0 technologies.

This new technology has changed the traditional way in which many of us collect, produce, and distribute geographic information. Before this, it was able to view more information passive consumers than producers in the first phase of World Wide Web known as Web 1.0 but with the advance of Web 2.0 the numbers of active data producers are increased (Vidal-Filho et al., 2013). The rapid development of Web 2.0 encourages users to share ideas, opinion, and information to others from around the world.

There are various VGI applications that allow users to upload and browse information in various media such as text, pictures, videos, and documents. The rapid growth of VGI projects in recent years such as OpenStreetMap, Google Map, Wikimapia, and Bing Map are some example of VGI web map sources that has successfully in providing timely and large amount of geographic information at low cost. Many scholars have done a research on VGI projects, namely OpenStreetMap (e.g.; Haklay, 2010; Arsanjani et al., 2013; Ballatore et al., 2013), Google Map and Bing Map (Cipeluch et al. 2010) and Flickr and Panoramio (Zielstra and Hochmair, 2013).

Conversely, there are some issues that are concerns among geographic information community related to the use of VGI such as credibility and quality of data (e.g; Elwood, 2008; Goodchild and Li, 2012; Idris et al., 2013; Forghani and Delavar, 2014). The credibility of data related with believability while the elements of data quality involve completeness, positional accuracy, attribute accuracy, logical consistency, currency, and lineage (e.g.; Girres and Touya, 2010; Neis et al., 2012). A possible explanation of these issues might be that the data is provided by non-professional individuals who have not good knowledge in geographic information.

The quality in the context of VGI is subjective depends on a user's requirement based on fitness for purpose and the benefit the users want to get (Coote and Rackham, 2008). For example, the decision maker in urban planning will look at completeness and currency of data quality elements to make sure decision process in management and design the cities are going smoothly. In mapping field, there are differences between VGI contributors versus individuals in professional mapping organizations in viewing quality assurance. VGI contributors normally will look at currency of data and reliability of feature attributes compared to professional in mapping organization which concern more on positional accuracy and completeness of coverage over a map tile (Coleman, 2013).

Even though there are some issues in VGI, there are potentials in implementing it for certain applications as shown in the next section. However, a scientific research is required to assure the practicality of VGI so that it can be beneficial to be used for various applications in example sustainable urban development.

\section{RESEARCH METHOD AND MATERIALS}

The scope of this study is restricted to the potential use of VGI for sustainable urban development application. Overview of the study is made based on gaps in research findings derived from past and current research. This method is one of the most effective ways to prepare for a review paper.

The literature was accessed using Web of Science (WoS) database. The keywords used in the search are "Volunteered Geographic Information”, "sustainable development" and "application" to search for relevant articles. Articles are sorted from newest to oldest publication and highest to lowest time cited. The search made in 2015 through WoS database generates 250 articles related to the VGI.

Besides that, Google Scholar is other sources that are used to access the literature. To enhance the review quality of this paper, relevant articles are selected. The results are analyzed to determine the potential use of VGI for sustainable urban development.

\section{VGI APPLICATIONS REVIEW}

Researches on the application of VGI were carried out by various scholars. This section describes the application of VGI based on three main pillars; social, economic, and environment that is related to sustainable urban development.

Cowley (2010) has investigated the potential use of mobile technology as one of the tools for citizens to provide and share geographic information related to urban planning. The mobile technology that is equipped with navigation system such as Global Positioning System (GPS) enable users to share their location and condition of the city in a real-time. This helps the planners and local authorities to monitor the city more efficiently.

Mooney et al. (2013) have investigated the potential use of VGI in pervasive health computing application. The study of OSM data for Ireland from 10th February until 13th October 2011 identify the growth of $36 \%$ in the number of points and polygon representing health service related features based on the six most frequently occurring "tags" in OSM; emergency, hospital, doctor, pharmacy, dentist, and health care. The advantages of applying VGI in pervasive health computing help the public to manage knowledge, answer questions and find health services in their place. Besides, VGI can provide researchers and organizations a dynamic view of the environment.

Conversely, Bakillah et al. (2014) have explored the potential use of VGI to estimate the population distribution at the building level. The population distribution is derived from 
interpolation techniques using data on building footprints and points of interest extracted from OpenStreetMap (OSM). The result of the case study in Hamburg, Germany shows that VGI can be used to estimate the population distribution.

Beaudreau et al. (2012) have developed a Geoweb called GeoActon (Figure 2) to allow the contribution of local business owners and general public in Acton, Quebec, Canada, providing valuable information related to their business or property to a map on the website. To contribute information to the web, users can add a point and fill in a form that describes their businesses for instance; contact information, photograph, business website, and other related information. Concerns with the quality of VGI, GeoActon allows users to correct error information in the application interface which generates a quality control email to the original author of the contribution to notify them of the changes. The benefit from the development of this website is all citizens in Quebec can get community asset information such as community parcels, tourism businesses, and manufacturing enterprises through the publicly accessible map. Besides, Through the development of the Geoweb, it can reduce the development cost and time, motivate users to contribute the information by enabling them to modify and update the information, and foster cooperation between stakeholders.

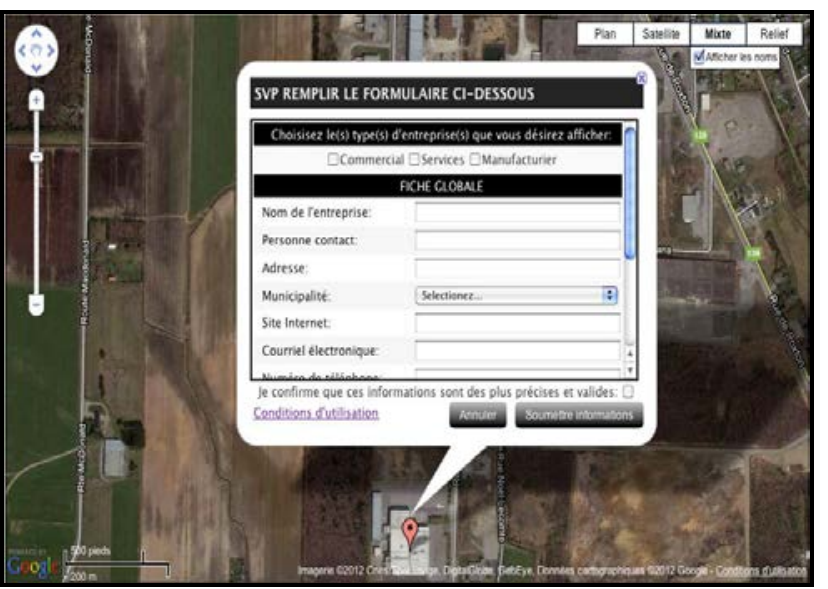

Figure 2: GeoActon interface for users to add and edit information (Source: Beaudreau et al., 2012)

Goeveia and Fonseca (2008) have proposed a framework that involves the combination of the concepts of traditional environmental monitoring networks with the ideals of the Web 2.0. The framework is developed as one of the ways to reduce the problem of data credibility and to encourage citizens to involve in providing environmental information. Meanwhile, Connors et al. (2012) discovered that environmental monitoring can benefit from the VGI. OakMapper project (Figure 3), a website developed by them allows researchers and private citizens to collect and share environmental data related to sudden oak death (SOD) disease at multiple geographic scales in California. The integration of VGI in this project has been able to gather geographic information on potential SOD disease in California.

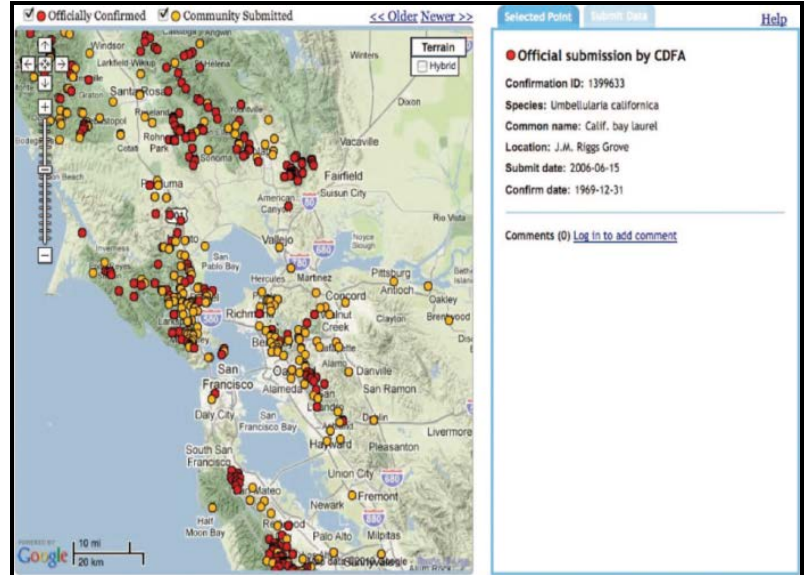

Figure 3: San Francisco Bay Area in OakMapper website (Source: Connors et al., 2012)

Other researchers has developed a Geoweb are Rickr et al., (2013). Google My Map is used as the Geoweb platform for Barbadians to participate in providing data for environmental change related with tourism activities in Barbados. A Geoweb workshop was held to welcome the participants that are from different kind of work sectors and age give information of environmental changes such as land use, erosion, point of interest, flooding, wildlife, pollution, temperature changes, tides, and green space by entering the data in Google My Map as shown in Figure 4. This contribution not only can give a benefit to the participant by increasing their knowledge related to environmental change, but also helps the local authority to manage economic development in Barbados.

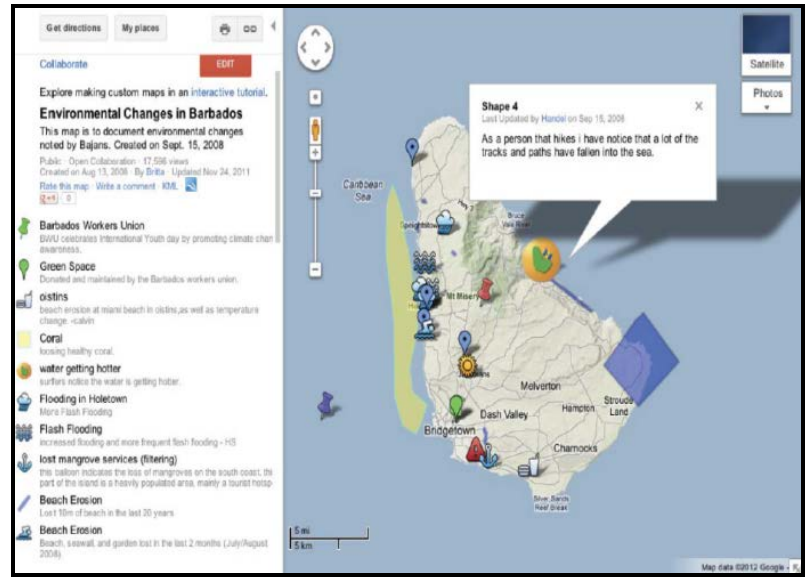

Figure 4: Google My Map interface and result in environmental change data in Barbados (Source: Rickr et al., 2013)

Zielinski et al. (2013) have developed an application for disaster management, specifically on preparedness phase, called TweetComp1. The intent of this application that using the Twitter platform is to provide real-time data, high data volumes in times of crises, and high accuracy of relevant information. The similar research has been carried out by Middleton et al. (2014) which developed a real-time crisis-mapping platform for natural disaster management. The tweet based platform is developed to improve the geoparsing precision and the accuracy of information which come from many sources. 


\section{THE POTENTIAL USE OF VGI FOR SUSTAINABLE URBAN DEVELOPMENT}

The rapid advancement of technology, social media such as Twitter, Facebook, and YouTube has a great potential to be used as one of the VGI data sources (Horita et al., 2013) as shown in previous research (e.g: Zielinski et al., 2013; Middleton et al., 2014). A research of Cowley (2010) also shows there has a good opportunity in using mobile technology as one of the VGI resources to understanding and planning of cities. The advantages of these technologies are giving fast response, up-to-date, huge volume of data and available information. Therefore, this section discusses the potential use of VGI for sustainable urban development application. Based on the previous section, Table 1 shows the summary of the review papers that are related to sustainable urban development application.

\begin{tabular}{|l|l|l|l|}
\hline Author (s) & Pillar & Application & VGI Platform \\
\hline $\begin{array}{l}\text { Goeveia and } \\
\text { Fonseca } \\
(2008)\end{array}$ & Environment & $\begin{array}{l}\text { Environmental } \\
\text { monitoring }\end{array}$ & $\begin{array}{l}\text { Environmental } \\
\text { Collaborative } \\
\text { Monitoring Network }\end{array}$ \\
\hline $\begin{array}{l}\text { Cowley } \\
\text { (2010) }\end{array}$ & $\begin{array}{l}\text { Social, } \\
\text { Economic, } \\
\text { Environment }\end{array}$ & Urban Planning & Mobile technology \\
\hline $\begin{array}{l}\text { Beaudreau et } \\
\text { al. (2012) }\end{array}$ & Economic & $\begin{array}{l}\text { Rural economic } \\
\text { development }\end{array}$ & GeoActon \\
\hline $\begin{array}{l}\text { Rickr et al., } \\
\text { (2013) }\end{array}$ & Environment & $\begin{array}{l}\text { Environmental } \\
\text { change }\end{array}$ & Google My Maps \\
\hline $\begin{array}{l}\text { Mooney et al. } \\
\text { (2013) }\end{array}$ & Social & $\begin{array}{l}\text { Pervasive health } \\
\text { computing }\end{array}$ & OpenStreetMap \\
\hline $\begin{array}{l}\text { Zielinski et } \\
\text { al. (2013) }\end{array}$ & Social & $\begin{array}{l}\text { Disaster } \\
\text { management } \\
\text { (Preparedness) }\end{array}$ & Twitter \\
\hline $\begin{array}{l}\text { Bakillah et } \\
\text { al. (2014) }\end{array}$ & Social & $\begin{array}{l}\text { Population } \\
\text { estimation }\end{array}$ & OpenStreetMap \\
\hline $\begin{array}{l}\text { Middleton et } \\
\text { al. (2014) }\end{array}$ & Social & $\begin{array}{l}\text { Disaster } \\
\text { management } \\
\text { (Preparedness) }\end{array}$ & Twitter \\
\hline
\end{tabular}

Table 1: Summary of VGI implementations in Social, Economic, and Environment applications

Based on the summary of the review paper in Table 1, five papers are discussed the application of VGI for the social pillar. While three papers discussed on the environmental pillar and only one paper found in economic pillar. Interestingly, the research of Cowley (2010) was carried out involves three interrelated pillars in urban planning applications. The VGI researchers develop a new VGI project based on the requirements of each application (e.g; Connors et al., 2012; and Beaudreau et al., 2012). However, there are also researchers that apply the existing VGI GeoWeb to be used in their applications (e.g.; Rickr et al., 2013; Mooney et al., 2013; and Bakillah et al., 2014).

There are many benefits of VGI based on previous researches that has been briefly described in section 5 in this paper which indirectly can be used for sustainable urban development application. The research on VGI applications based on environment pillar is commonly being used for environmental monitoring that support planning (e.g.; Goeveia and Fonseca, 2008; Rickr et al., 2013). VGI is the crucial decision support environment for gathering knowledge about a place in sustainable urban development. The layering of various sitesassessment data in VGI gives the clearest possible picture of a site, and the effect to the environment due to the development will have on the surrounding area. So that local authority can preserve and conserve the environment in the area more efficient. In addition, the involvements of citizens in sharing information indirectly encourage them to protect the environment. The VGI data is not only can be used in monitoring the environment, but is useful to the society for disaster management in four phases; mitigation, preparedness, response, and recovery (Goodchild and Glennon., 2010; Poser and Dransch, 2010; Horita et al., 2013).

Moreover, VGI can be beneficial in terms of economic development (Beaudreau et al., 2012). The local authorities for instance, can identify which location has many commercial areas and industry so that they can monitor which area should develop more or maintain. Indirectly, it can help in reducing urban poverty problem which increases job opportunities in the area. Through this kind of economic related data, it can help decision maker to evaluate, monitoring and generate socioeconomic development in an area.

Furthermore, VGI is ultimately contributing to the social related data in sustainable urban development (e.g; Mooney et al., 2013; Zielinski et al., 2013; Bakillah et al., 2014; Middleton et al., 2014). The VGI data can be utilized in planning to help urban planners monitor land use changes due to the increase of population in an area. Based on VGI data, local authorities can improve and manage social service delivery to the community. In fact, it can help the government's efforts around the world to achieve the target of spatially enabled society (Ho and Rajabifard, 2010).

However, there are some issues to implement VGI in planning. VGI sources generated by users who have different levels of expertise in geographic information causes the VGI quality are variable. So, a method to assure the accuracy and validity of volunteer data is needed to make sure the VGI is suited to the planning application (Cowley, 2010). Besides, the issue of engaging the cooperation between local authority and public to participate in providing real time geographic information is needed to consider because real time information needs constant monitoring and management. This is supported by Seltzer and Mahmoudi (2012) which states participation in providing information is the leisure time activity for citizens. Other challenge in using VGI for planning is data storage, data management, and data sharing. Convergence on the study of VGI and Spatial Data Infrastructure (SDI) should be conducted (McDougall, 2009; Castelein et al., 2010) to get a solution of spatial data storage, data management, and data sharing issues.

\section{SUMMARY}

In summary, citizens, including professional and nonprofessional peoples have started to realize the benefit of VGI. In recent years, researchers have started to explore the potential of VGI for various applications. The examples of VGI application describe above indicate some of the ways urban planners can make use of recent developments in VGI which is indirectly can be applied in sustainable urban development application. Citizens can participate by sharing location, photos, video or text about the conditions of the city based on their local knowledge. The decision makers, including urban planners and local authorities can get an up-to-date data and save the cost in measuring the sustainability of urban development by motivating citizens voluntarily to participate in providing information. A good collaboration between decision makers, academia, and general citizens can be built in better planning the city. Nonetheless, important matters that are related to geographic data should be considered such as the quality and credibility of the data. The author suggests a scientific research is required to assure the quality of VGI so that it can be beneficial to be used as a source in measuring the sustainability 
of urban development which involves the three interrelated aspects; social, economic, and environment.

\section{ACKNOWLEDGEMENT}

The authors wish to acknowledge Universiti Teknologi Malaysia (UTM) for Research University Grant Vote Q.130000.2427.02G77 and Vote R.130000.7827.4121 to finance this study.

\section{REFERENCES}

Ariffin, I., Solemon, B., Anwar, R. M., \& Azmi, N. N. (2014). Exploring the Potential of Volunteered Geographic Information as a Source for Spatial Data Acquisition. In 7th IGRSM International Remote Sensing \& GIS Conference and Exhibition, 22-23 April 2014, Kuala Lumpur, Malaysia.

Arsanjani, J. J., Helbich, M., Bakillah, M., Hagenauer, J., \& Zipf A. (2013). Towards mapping land use pattern from volunteered geographic information. International Journal of Geographical Information Science, 27(12), pp 2264-2278. DOI: 10.1080/13658816.2013.800871.

Bakillah, M., Liang, S., Mobasheri, A., Arsanjani, J. J., \& Zipf, A. (2014). Fine-resolution population mapping using OpenStreetMap points-of-interest. International Journal of Geographical Information Science, 28(9), pp 1940-1963. DOI: 10.1080/13658816.2014.909045.

Ballatore, A., Bertolotto, M., \& Wilson, D. C. (2013). Geographic knowledge extraction and semantic similarity in OpenStreetMap. Knowl Inf Syst (2013) 37:61-81. DOI: 10.1007/s10115-012-0571-0.

Beaudreau, P., Johnson, P. A., \& Sieber, R. E. (2012). Strategic choices in developing a geospatial web 2.0 application for rural economic development. Journal of Rural and Community Development, 7(3), pp 95-105.

Broekhof, S., \& Marwijk, R. (2012). The Role of Spatial Information for Planning Sustainable Cities. In FIG Working Week 2012 on Knowing to Manage the Territory, Protect the Environment, Evaluate the Cultural Heritage, 6 - 10 May 2012, Rome, Italy.

Castelein, W., Grus, L., Crompvoets, J., \& Bregt, A., (2010). In 13th AGILE International Conference on Geographic Information Science 2010, Guimarães, Portugal.

Ciegis, R., Ramanauskiene, J., \& Martinkus, B. (2009). The Concept of Sustainable Development and its Use for Sustainability Scenarios, Inzinerine Ekonomika-Engineering Economics (2).

Cipeluch, B., Jacob, R., \& Winstanley, A. (2010). Comparison of the Accuracy of OpenStreetMap for Ireland with Google Maps and Bing Maps. In Accuracy 2010 Symposium, July 2023, Leicester, United Kingdom.

Coleman, D. J., Georgiadou, Y., \& Labonte, J. (2009). Volunteered Geographic Information: the nature and motivation of producers. International Journal of Spatial Data Infrastructures Research, Special Issue GSDI-11.
Coleman, D. J. (2010). Volunteered Geographic Information in Spatial Data Infrastructure: An Early Look at Opportunities and Constraints. Spatially Enabling Society: Research, Emerging Trends and Critical Assessment (2010), pp 1-18.

Coleman, D. J. (2013). Potential Contributions and Challenges of VGI for Conventional Topographic Base-Mapping Programs. In: Sui, D., Elwood, S., and Goodchild, M., 2013, Crowdsourcing Geographic Knowledge: Volunteered Geographic Information (VGI) in Theory and Practice, Springer Dordrecht Heidelberg, New York, London, 307-327.

Connors, J. P., Lei, S., \& Kelly, M. (2012) Citizen Science in the Age of Neogeography: Utilizing Volunteered Geographic Information for Environmental Monitoring, Annals of the Association of American Geographers, 102(6), pp 1267-1289. DOI: 10.1080/00045608.2011.627058.

Coote, A. and Rackham, L. (2008). Neogeographic data quality - is it an issue? In Annual Conference of the Association for Geographic Information (AGI), September 2008.

Cowley, J. E. (2010). Planning in the Real-Time City: The Future of Mobile Technology. Journal of Planning Literature, 25(2), pp 136-149. DOI: 10.1177/0885412210394100.

Elwood, S. (2008). Volunteered geographic information: future research directions motivated by critical, participatory, and feminist GIS. GeoJournal, 72, pp 173-183.

Forghani, M., \& Delavar M. (2014). A Quality Sudy of OpenStreetMap Dataset for Tehran. ISPRS Int. J. Geo-Inf. 2014, 3, pp 750-763. DOI: 10.3390/ijgi3020750.

Genovese, E., \& Roche, S. (2010). Potential of VGI as a Resource for SDIs in the North/South Context. Journal of Geomatica, 1-15.

Girres, J. F., \& Touya, G. (2010). Quality Assessment of the French OpenStreetMap Dataset. Transactions in GIS, 2010, 14(4): 435-459. DOI: 10.1111/j.1467-9671.2010.01203.x.

Goodchild, M. F. (2007). Citizens as sensors: the world of volunteered geography. GeoJournal (2007), 69 pp 211-221. DOI 10.1007/s10708-007-9111-y.

Goodchild, M. F., \& Glennon, J. A. (2010). Crowdsourcing geographic information for disaster response: a research frontier. International Journal of Digital Earth, 3(3), 231-241. DOI: http://dx.doi.org/10.1080/17538941003759255.

Goodchild, M. F., \& Li, L. (2012). Assuring the quality of volunteered geographic information. Spatial Statistics 1 (2012), 110-120. DOI: 10.1016/j.spasta.2012.03.002.

Gouveia, C., \& Fonseca, A. (2008). New approaches to environmental monitoring: the use of ICT to explore volunteered geographic information. GeoJournal (2008), 72, pp 185-197. DOI: 10.1007/s10708-008-9183-3.

Green, M. L., Espinal, L., Traversa, E., \& Amis, E. J. (2012). Materials for sustainable development. MRS Bulletin, 37(4), pp 303-309. DOI:10.1557/mrs.2012.51.

Grimm, N. B., Foster, D., Groffman, P., Grove, M. J., Hopkinson, C. S., Nadelhoffer, K. J., Pataki, D. E., and Peters, D. PC. (2008). The Changing Landscape: Ecosystem Responses 
to Urbanzation and Pollution Across Climatic and Societal Gradiations. Journal of Front Ecol Environment, 6(5), pp 264272.

Haklay, M. (2010). How Good is Volunteered Geographic Information? A Comparative Study of OpenStreetMap and Ordnance Survey Datasets. Environment and Planning B: Planning and Design 2010, 37, pp 682-703. DOI: 10.1068/b35097.

Ho, S., \& Rajabifard, A. (2010). Learning From the Crowd: The Role of Volunteered Geographic Information in Realizing a Spatially Enabled Society, GSDI 12 World ConferenceRealizing spatially enabled societies, 2010, pp. 1-23.

Horita, F. E. A., Assis, L. F. F. G., Degrossi, L. G., \& Zipf, A., and Albuquerque, J. P. (2013). The use of Volunteered Geographic Information and Crowdsourcing in Disaster Management: a Systematic Literature Review. In Proceedings of the Nineteenth Americas Conference on Information Systems, August 15-17 2013, Chicago, Illinois, United States.

Idris, N. H., Jackson, M. J., \& Ishak, M. H. I. (2014). A Conceptual Model of the Automated Credibility Assessment of the Volunteered Geographic Information. In 8th International Symposium of the Digital Earth (ISDE8), 26-29 August 2013, Kuching, Sarawak, Malaysia.

McDougall, K. (2009). Volunteered Geographic Information for Building SDI. In: Ostendorf, B., Baldock, P., Bruce, D., Burdett, M. and Corcoran, P. (eds.), Proceedings of the Surveying \& Spatial Sciences Institute Biennial International Conference, Adelaide 2009, Surveying \& Spatial Sciences Institute, pp. 645-653. ISBN: 978-0-9581366-8-6.

Middleton, S.E., Middleton, L., \& Modafferi, S. (2014). RealTime Crisis Mapping of Natural Disasters Using Social Media. Intelligent Systems, IEEE, 29(.2), pp.9-17. DOI: 10.1109/MIS.2013.126.

Mooney, P., Corcoran, P., \& Ciepluch, B. (2013). The potential for using Volunteered Geographic Information in Pervasive Health Computing Applications. J Ambient Intell Human Comput (2013) 4:731-745. DOI: 10.1007/s12652-012-0149-4.

Neis, P., Zielstra, D., \& Zipf, A. (2012). The Street Network Evolution of Crowdsourced Maps: OpenStreetMap in Germany 2007-2011. Future Internet 2012, 4, pp 1-21. DOI: 10.3390/fi4010001.

Poser, K., \& Dransch, D. (2010). Volunteered geographic information for disaster management with application to rapid flood damage estimation. Geomatica, 64(1), pp 89-98.

Ricker, B. A., Johnson, P. A., \& Sieber, R. E. (2013). Tourism and environmental change in Barbados: gathering citizen perspectives with Volunteered Geographic Information (VGI). Journal of Sustainable Tourism, 21(2), pp 212-228. DOI: 10.1080/09669582.2012.699059.

Scherrer, Y. M. (2009). Environmental Conservation NGOs and the Concept of Sustainable Development. Journal of Business Ethics, 555-571. DOI: 10.1007/s10551-009-0211-0.

Schoolman, E. D., Guest, J. S., Bush, K. F., \& Bell, A. R. (2012). How interdisciplinary is sustainability research? Analyzing the structure of an emerging scientific field.
Sustainability Science, 7(1), pp 67-80. DOI:10.1007/s11625011-0139-z.

Seeger, J. C. (2008). The role of facilitated volunteered geographic information in the landscape planning and site design process. Geojurnal, 72, pp 199-213.

Seltzer, E., \& Mahmoudi, D. (2012). Citizen Participation, Open Innovation, and Crowdsourcing: Challenges and Opportunities for Planning. Journal of Planning Literature, 28(1), pp 3-18. DOI: 10.1177/0885412212469112.

Song, W., \& Sun, G. (2010). The Role of Mobile Volunteered Geographic Information in Urban Management. Geoinformatics. 18th International Conference. Beijing.

United Nations (1987). Report of the World Commission on Environment and Development: Our Common Future.

United Nations - Habitat (2006). In World Urban Forum III, An International UN-Habitat Event on Urban Sustainability, 19 23 June, 2006, Vancouver, Canada.

Vidal-Filho, J. N., Lisboa-Filho, J., Souza, W. D., \& Santos, G. R. (2013). Qualitative Analysis of Volunteered Geographic Information in a Spatially Enabled Society Project. SpringerVerlag Berlin Heidelberg, pp 378-393.

Xing, Y., Horner, R. M. W., El-Haram, M. A., \& Bebbington, J. (2009). A Framework Model for Assessing Sustainability Impacts of Urban Development. Accounting Forum 33, pp 209224

Yusof, F., Rostam, K., \& Muhammad, Z. (2008). Bandar Berdaya Saing vis-a-vis Pembangunan Lestari: Suatu Wacana Tentang Pembangunan Bandar di Malaysia. Malaysian Journal of Society and Space, 4, 85-98.

Zielinski, A., Middleton, S. E., Tokarchuk, L. N., \& Wang, X. (2013). Social Media Text Mining and Network Analysis for Decision Support in Natural Crisis Management. In Proceedings of the 10th International ISCRAM Conference, May 2013, Baden-Baden, Germany.

Zielstra, D., \& Hochmair, H. H. (2013). Positional accuracy analysis of Flickr and Panoramio images for selected world regions. Journal of Spatial Science, 58(2), pp 251-273. DOI: 10.1080/14498596.2013.801331. 